\title{
Alienation and Therapy in Existentialism: A Dual Model of Recognition
}

\author{
Gillian Howie
}

Accepted: 15 July 2013 / Published online: 2 October 2013

(C) The Author(s) 2013. This article is published with open access at Springerlink.com

\begin{abstract}
Many philosopers and social theorists pursue the notion that recognition is a fruitful framework for engaging with a social analysis of moral and political life, and - more critically - that the failure of recognition is a feature of alienation. This article argues that the thrust of these arguments can be properly attuned by deploying a dual model of recognition that draws especially on Sartre's work. Where there is struggle for recognition between subjects, the object of struggle is not the recognition of identity, or even of difference, but the recognition of non-identity. The claim will be that this practical attitude of recognition designates inter-subjective attitudes that can institute normative practices whereby agents' claims are motivated by the epistemic virtue of non-identity.
\end{abstract}

Keywords Alienation · Recognition · Nonidentity · Sartre

\section{Introduction}

There is an ever-increasing number of philosophers and social theorists interested in the relationship between identity and recognition pursuing the notion that recognition is a fruitful framework for engaging with a social analysis of moral and political life, and more critically - that the failure of recognition is a feature of alienation. ${ }^{1}$ It is my broad contention that the thrust of these arguments can be properly attuned by deploying a dual model of recognition. Philosophical therapy reveals that, understood in one way, the failure to recognise identity is an appropriate response to the struggles of consciousness; specifically the struggle between consciousnesses. Where there is struggle for recognition between subjects, the object of struggle is not the recognition of identity, or even of difference, but for the recognition of nonidentity. The claim will be that this practical attitude of recognition designates inter-subjective attitudes that can institute normative practices whereby agents' claims are motivated by the epistemic virtue of nonidentity. Relevantly, this will be coupled with a phenomenological description of the primary (self) relation, articulated through the

\footnotetext{
${ }^{1}$ This is true even when 'recognition' is interpreted not along the lines of identity but of status and exclusion. See Nancy Fraser (2002, 23-5).

Gillian Howie, formerly Professor of Philosophy and Head of the Department of Philosophy at the University of Liverpool, sadly died in March 2013.
}

G. Howie $(\bowtie)$

Department of Philosophy, 7 Abercromby Square, Liverpool L69 7WY, UK

e-mail: g.howie@liv.ac.uk 
pre-reflective cogito, as one that is necessarily self-divided. With reference to Hegel's description of the Unhappy Consciousness, I identify this 'self-division' as estrangement in order to differentiate it from Marx's concept of alienation which I will relate to what has come to be called 'the status model of recognition'.

\section{Philosophy and Therapy}

Philosophy is primarily an intellectual discipline concerned with concepts, theories, ideas reason and argument. Therapy is a form of treatment intended to heal or relieve a body, mental or behavioural disorder or disease by some remedial rehabilitation or curative process. It would seem unlikely that an intellectual discipline could ease suffering or, more ambitiously, be curative and bring about health. Further, there is a deeper suspicion that philosophy is indifferent to the prosaic, to the mundane or the sensual and that philosophers can be caricatured as lofty, bearded and anachronistic beings who believe that they have insights into the meaning of life but are disinclined to consider if not quite the commonplace - for the content of philosophical reflection is very often the everyday and apparently obvious - but rather the social and personal context within which reflection occurs. Philosophers, as strangers to the everyday and aspiring to be free from the demands of the particular and quotidian, seem completely the wrong people to ask about fear, loss, pain and suffering.

Although on the face of it, the appeal to philosophy to alleviate suffering appears to be a category error, an association of philosophical and therapeutic practice can employ an ancient alignment of philosophical method, medical practice and cure that is integral to Buddhist and non-Buddhist Indian philosophical traditions as well as ancient Greek philosophies (Gowans 2010, 14). ${ }^{2}$ Echoing across all these traditions, and more recently through Wittgensteinian and pragmatist philosophy, is the notion not only that philosophical practice can help to cure mental or spiritual disorder and restore psychological health but also that this is its singular purpose and achievement. These traditions present ways in which psychological health can be restored through the exercise of reason, which can iron out linguistic confusion, excise poorly formulated or inadequately justified beliefs and identify the cause of unpleasant emotional affect.

This ancient practice of philosophy is not solely a technical exercise that aims at the acquisition of purely abstract knowledge or logical exactitude. ${ }^{3}$ Within the ancient Greek tradition philosophical practice is not the same as the construction of abstract theories of physics, logic or ethics. The important contrast lies between abstraction and practice rather than, say, between ethics and physics. ${ }^{4}$ The exercise of reason and the amelioration of

\footnotetext{
${ }^{2}$ Six schools of the Hellenistic period included Stoicism; Epicureanism; Platonism; Aristotelianism; Cynicism and Pyrrhonism.

${ }^{3}$ Drawing on a distinction between théorique and théorétique, Hadot (1995) suggests that while the former meaning is antithetical to practical philosophy, the latter combines practice and intellectual rigour (theoria). Due to a natural inclination to be satisfied with propositional architecture, the severance of religious from philosophical concern and the emergence of the European University, with its disciplinary and professional boundaries, théorique came to dominate philosophy.

${ }^{4}$ Hadot draws a distinction between his description of spiritual exercise and those developed by Foucault at this point: Foucault, according to Hadot, was not able to see the full scope of spiritual exercises, that physics (and logic) as much as ethics, aimed at self-transformation. He was also concerned that Foucault's description of ethics of care slipped into an ethics of pleasure; an altogether different thing from joy. For him, these two aspects, denial of physics and concentration on pleasure, led to Foucault mistaking the relationship of the individual to the whole and to propound a 'new form of Dandyism, late twentieth century style' (Hadot 1995, 211).
} 
unhelpful belief states were combined with what Gowans describes as an array of exercises including: the close observation of mental states, modification of habits, anticipation, postponement, distractions, invocation of role-models, self-examination and confession (cf. Gowans 2010). Each exercise calls us to attend to the dynamic unity of reality, the self and relations with others. The practice of these exercises and the existential attitude thereby engendered might result in a radical conversion; an abrupt change of way of life. It involves learning how to live a good life and this practical art, more often than not, requires a transformation of world view and metamorphosis of personality (Hadot 1995). The restorative potential of philosophical practice lies in the possibility that spiritual exercises may elicit a form of life lived with clarity, tranquillity and happiness: all of which involve the absence of emotional turbulence. Indeed, for Plato the purification of the soul and its separation from the passionate and suffering body is the true practice of philosophy and training for death (Phaedo, $67 \mathrm{c}-\mathrm{d}$ ).

These same spiritual exercises can be justified by extremely diverse philosophical discourses (Hadot 1995, 212) and it is possible to reassemble key components of them without presupposing a philosophical commitment to the unity of reason, the identification of tranquillity with the good life and the idea that philosophy is training for death. The practical element of these exercises, the cultivation of the self, is described by Michel Foucault as an exercise of the self on the self through which one attempts to transform oneself and attain a certain mode of being (Foucault 1986, 282). This 'care of the self' is primarily an ontological 'knowing of oneself' and one's capacities (ibid., 288): an interiorisation inseparably linked to an exteriorisation and a new way of being-in-the-world (Hadot 1995, 211).

\section{Alienation and Existentialism}

What if the existential attitude, the calling of our life into question, is just that which we apprehend as anxiety? What if the condition of philosophy, the ability to ask a question about the world before us, is exactly that which leads to turbulence? Man, says Sartre towards the end of Being and Nothingness, is a useless passion: striving towards something which is impossible. Sartre's existentialist phenomenology offers an opportunity to test the therapeutic possibilities and limits of philosophical practice through its assertion that consciousness contains within itself division which is not only the condition of exteriorisation but also anxiety, bad faith and political alienation. ${ }^{5}$ In grappling with this, Being and Nothingness involves itself in an elaborate methodological circle whereby phenomenology - the reflective exploration of what it is to be human - is evidenced through its therapeutic or practical aspect and this therapeutic aspect provides support for the philosophical ontology (Morris 2008, xii). In addition, existentialist phenomenology is able to engage with prejudicial structures that not only shape our thinking but also our somatic and affective being-in-the-world. Therapeutically, it is thus able to offer insight into the conditions of experience that allow for the critical dissolution of illusion and alter habitual harmful behaviours which, with practice, could prompt a radical conversion. In the process, it shows how to live a life always in question. Finally, we return to Marx's analytic distinction

\footnotetext{
5 'When interest awakens in such questions (freedom and praxis), there is no doubt that the paths to be taken by those who ask them will lead in each case through Sartre's works. His insights, his concerns, his answers are in no case definitive; but politically and theoretically he commands attention for having lived and thought them so fully, so courageously, so deeply' (Aronson 1987, xii).
} 
between objectification and alienation to see how Sartre's notion of being-in-the-world might support a secondary political model of recognition.

\subsection{Being for-Self}

Just as the first few sections in the Phenomenology of Spirit reveal how to appreciate the term 'alienation', that it applies not only to objectification but also to externalisation and is associated with the anguish of a self who is divided from him or herself, so too with Being and Nothingness. ${ }^{6}$ The characterisation of consciousness in Being and Nothingness takes the form of a regressive argument. Sartre describes quotidian and thoroughly everyday experience and postulates what must be the case for this to be possible. Similar to the structure of a transcendental argument, Sartre contends that the pre-reflective cogito is the necessary condition of the possibility of (negative) experience. Of this he makes two further claims. Firstly, that there emerges a space between the thinking subject and that which is the object of thought; between the perceiving subject and that which is perceived at a pre-reflective level. Secondly, human reality is a perpetual surpassing towards a coincidence with itself which is never given. In this section I furrow out the potential of this 'spacing', or estrangement, within consciousness.

Sartre takes issue with Husserl's notion of the subject as transcendental ego and distinguishes between pre-reflective and reflective consciousness in the slightly earlier The Transcendence of the Ego (Sartre 1957, 44-8). ${ }^{7}$ Pre-reflective consciousness intends or posits an object other than itself. The very fact of having something as its object means that consciousness is separate from its object and capable of distinguishing itself from it: 'there emerges a space between the thinking subject and that which is perceived' (Warnock 1972, xi). Pre-reflective consciousness is not only aware of objects (other than itself) but also aware of itself perceiving these objects. As a consequence, pre-reflective consciousness is simultaneously consciousness of an object, other than itself, and non-positionally self-aware (Busch 1980, 19). The claim is that consciousness is accompanied by internal consciousness or non-thematized self-awareness and that subjectivity is 'spontaneous reflexivity of consciousness when it is directed towards something other than itself'.

In Being and Nothingness (Sartre 2003), Sartre explains how reflexivity avoids infinite regress and thereby also demonstrates that the pre-reflective cogito is neither a stable nor a substantial identity. First, there is a doubling of consciousness and this is our everyday experience (awareness of an object $\mathrm{x}$ is accompanied by an awareness of this awareness-x). Second, (self) awareness of the intentional object is only possible if there is a caesura or distance within consciousness. The 'self', in pre-reflective (self) consciousness, indicates a relation but of what type? The doubling of consciousness, reflexivity, is no 'game of reflections' because whilst consciousness is a reflection (reflet) qua reflection it is exactly the one reflecting (réfléchissant). If we attempt to grasp this reflecting in its distinctness, we find that it vanishes. This is because the structure - reflet-reflétant - is not a relationship either to the infinite or to a single and unified self. The presence of the self 'to itself' depends on there being a break within consciousness which cannot itself be captured. 'If being is present to itself', he writes 'it is because it is not wholly itself. Presence is an immediate

\footnotetext{
${ }^{6}$ According to Judith Butler, the transition from 'Lordship and Bondage' to the 'Unhappy Consciousness' is rather neglected in Hegelian scholarship but is pivotal to Foucault's appraisal of the double-moment of the subject: its articulation as subjectivity and its reflexive application of ethical laws (Butler 1997, 33).

${ }^{7}$ For our purposes it does not matter how the concept of the person shifted through these earlier writings (Transcendence of the Ego, Emotions, Psychology of the Imagination and Being \& Nothingness).
} 
deterioration of coincidence, for it supposes separation'. This fissure within consciousness is nothing. I am, nonetheless and by dint of the same argument, aware of these experiences of the world as 'mine'. I am aware of these experiences of the world as 'my' experiences, although 'my-ness' in the world is a fugitive structure (2003, 128). This means that (self) awareness of the world is a way of not coinciding with oneself and presence is precisely that which prevents and escapes identity $(2003,101)$. 'The subject may be deferred, dissolved and deconstructed, but it is not relinquished' (Howells 1992, 342).

One upshot of this description of non-positional consciousness is that there is a permanent possibility of dissociating the self from the causal series and that, therefore, consciousness is free. We can also become conscious of this freedom. ${ }^{8}$ It is by anguish that man becomes conscious of his freedom, or in other words anguish is the mode of being of freedom as a consciousness of being (Sartre 2003, 53). Echoing Hegel's description of consciousness as unhappy, inwardly disrupted and wretched 'passing backwards and forwards in a baffling and bewildering manner from the idea that it is self-identical and essential to the idea that it is merely contingent', Sartre describes consciousness struggling to come to terms with its own nature which, because it is divided, is free and because it is free, is anguished. For example, unlike fear, which is a perfectly reasonable response to a dangerous situation, anguish is 'a terrifying vertigo of possibility' (Morris 1976, 82). It reveals that nothing prevents me from precipitating myself into the abyss. We flee anguish by alienating our freedom either by trying to look at ourselves from outside, as another person or thing, or by thinking of ourselves as compelled or determined.

Sartre outlines various patterns of bad faith which are ways of living with, and avoiding the fact of, a transcending consciousness and the lack of coincidence in identity. That said, by virtue of our embodiment we have a past, a situation, a being-in-the-world. Bad faith, writes Sartre, seeks to flee the inner disintegration of being by denying its inner disintegration. The patterns and attitudes that constitute the Weltanschauung of bad faith are attempts to flee the inner disintegration of being by either denying the character of consciousness or the reality of the situation. One example is the demand for sincerity. Take a case where someone believes that his friend really prefers to conduct sexual relations with younger members of the same sex but is so embarrassed and guilty about it that he denies it to be the case. ${ }^{9}$ The friend demands that the man admit to his feelings: to identify himself as a particular way of being-in-the-world. In response, the man considers that he is not a pederast, in the same way that a table is a table.

This is right, says Sartre, insofar as 'I am not what I am'. I can call into question at any moment that which I have been as the foundation for that which I will be. It would be wrong in the case where I attempt to assert a simple identity such as 'an inkwell is not a table'. I cannot simply choose to deny my past actions, my facticity and my situation. However, what is far worse is the demand made that the man should identify himself at all. There is latent brutality in the demand that in the name of freedom the man should identify as a thing-initself, as a 'personality'; or that for the sake of freedom he should deny his freedom. This man's freedom relates directly to the structure of his consciousness and nothingness: He is what he is not. Being and Nothingness is an attempt to capture how a subject can both relate to the facticity of their situation and to the nature of consciousness: a relationship which

\footnotetext{
${ }^{8}$ Aware of its own nothingness, consciousness duplicates within itself the relationship of master and servant (Hegel 1977, 125). According to Butler, this is for Foucault the articulation of the moment of 'selfenslavement'

${ }^{9}$ Sartre switches between homosexual and pédéraste. This latter term originates from the Greek usually to refer to a man who has an erotic relationship with male adolescent. Although the terms are not synonymous, pederasty is often confused with paedophilia.
} 
Sartre expresses in the well-known formula 'I am what I am not and I am not what I am'. This is a case for ontological nonidentity. ${ }^{10}$

Consciousness is such that human reality is a perpetual surpassing towards a coincidence with itself which is never given (gap, caesura, nothingness). These immediate structures of the for-itself allow consciousness to introduce value, meaning and purpose into the world and give rise not only to a variety of projects but also to a fundamental project. The actions of an individual reveal a unique project: 'a word that condenses into a single drop a cloud of meanings and values... a way or attitude of being-in-the-world' (Morris p152). Yet, if we excavate even further we find that each fundamental project is motivated by cognitive values identified as those of 'seriousness': permanence, essentialism, moral realism. Indeed, the fundamental project is animated by a desire 'to be God', conscious in-itself without the distance within consciousness. The elimination of distance within consciousness is a vain ambition and for this reason Sartre describes man 'as a useless passion'.

As he concludes Being and Nothingness, Sartre proclaims that phenomenological ontology cannot ground ethical principles: as it is concerned solely with what is, it is moral description. It has revealed that consciousness, as nothingness, is the origin and nature of value. Between the past which no longer is, and the future which is not yet, this moment when the subject exists is nothing. Further, and this he suggests might allow us to catch a glimpse of an ethical attitude, intentional, embodied consciousness is always object-related and situated. Many are tempted to try to eliminate the tragic ambiguity of their condition either by making themselves pure inwardness or pure externality, by escaping from the external world or being engulfed by it (Beauvoir 1976, 8). Psychoanalytic existentialism can help to reveal the underlying values motivating the fundamental project and encourage in the subject a heightened sense that they are the creator of meaning and value. The therapeutic aim is for the subject to affirm him or herself as creator of all value rather than define him or herself in terms of a transcendent value that haunts every project. To undergo this 'radical conversion', I would have to accept the troubling fact that my 'self', as creator of meaning, is a way of not being my own coincidence and that my 'personality' is a public construct held in place by belief. Rather than going beyond or overcoming the estrangement of the self from the self, I, as subject, affirm this irreducible character of ambiguity. This is not an elimination of anxiety but through awareness of self such explanation that could lead to a change in attitude towards belief and action.

\subsection{Being for-Others}

We begin with the lived experience of the conscious fleshy body situated within a world and, from the above characterisation of consciousness, we can see there is no neutral cognitive stance towards the world: no view-from-nowhere. ${ }^{11}$ In this section, I consider the "third ekstasis' of being for-itself: being for-others. This third dimension of being is the foundation for claims about intersubjectivity and the ethics of recognition (Heter 2006, 17). I investigate

\footnotetext{
${ }^{10}$ The term 'nonidentity' is most commonly associated with critical theory, in particular Theodor Adorno. According to Adorno nonidentity indicates that every object subsumed under a class term has characteristics that are not contained within the class: indeed a quality that cannot be expressed in propositional form. Something both is and is not its concept. See Howie (2010, 118-122 and 135).

${ }^{11}$ Honneth (2008) wishes to establish a family resemblance between Heidegger's 'care', Dewey's concept of practical involvement and Lukács's 'engaged praxis', brought together as 'recognition', such that all agree that the stance of empathetic engagement in the world, arising from the experience of the world's significance and value, is prior to our acts of detached cognition (ibid., 111). More radically, Sartre would argue that there is no such thing as detached cognition.
} 
the moral content of recognition and shall suggest that it is most helpful to think of this in terms of a practical attitude to the other governed by epistemic virtues that may or may not run in parallel with positive emotions. On the surface, it looks as though Sartre describes the self-other relationship as an irresolvable struggle for recognition of identity, thereby suggesting an individualised and competitive anthropology. This could lead to one of two claims: the struggle for recognition of identity is unavoidable or that Sartre incorrectly identifies it as an a priori of human relations when it is, instead, a feature of alienation and a form of 'distorted' practice. It is my contention however that where there is struggle, it is actually a struggle against the recognition of identity. If correct in this assumption, existentialist phenomenology undermines the notion that 'recognition of identity' can be a normative condition of social interaction. The attribution and demand for recognition is actually for the recognition of nonidentity. It remains to be decided if 'recognition', whether of identity or nonidentity, requires empathy, sympathy or a positive psychological stance.

Arguing that neither idealism nor realism has an appropriate response to solipsism, Sartre argues that — rather than trying to prove the existence of others or offer a philosophical refutation of their existence - we should begin with our concrete encounters. Whereas realism attempts to establish the existence of the other through reasoning by analogy and idealism takes otherness as a regulative concept, Sartre suggests that the relationship between self and other is internal rather than external. We encounter others not as objects in the world but as subjects who modify our own experience. There is an attitude, he says, that reveals an intimate relation of me to myself through the mediation of others. To escape from solipsism I need no proof of the other's existence because I implicitly and unreflectively acknowledge others in my everyday life. The modification of consciousness precedes a psychological inclination or affectation to 'put oneself in another's position' and implicates each in the emotional life of the other. ${ }^{12}$ He demonstrates the quotidian character of this relationship through three examples of 'The Look'. The first example is that of a walk in the park, whereby the existence of the other as subject is concretely revealed to me when I am aware that the other as subject is a focal point for their world - a world within which I am an object. The second example, a surprise attack on a farmhouse, is intended to show not only that my transcendence is transcended but that the look refers me to myself. The third example, where the subject is caught listening at the keyhole, begins to unravel the complex character of recognition.

I put my ear to the door. I am alone and am absorbed in listening to what is being said. At this level of non-thetic self-consciousness there is no self that inhabits my consciousness. I simply am listening. I hear footsteps and realise that someone could find me crouched behind the door. I now exist for myself as pre-reflective cogito. The self comes to haunt prereflective consciousness but it is self as object for other. I am consciousness that I have my foundation outside myself. My 'self' is an object in the world because it is an object for others. I have a foundation outside myself. I am for myself in reference to the other. I grasp the other's look at the centre of my action as solidification and alienation of my possibilities. I am crouched here listening just as an inkwell is on the table. I am someone. Who am I? I am she in midst of the world. The other apprehends my possibilities, surpasses them and this effects a subtle death. The other is the hidden death of my possibilities as I live them in the

\footnotetext{
${ }^{12}$ Honneth writes 'the act of placing oneself in the perspective of a second person requires an antecedent form of recognition that cannot be grasped in purely cognitive or epistemic concepts, as it always and necessarily contains an element of involuntary openness, devotedness or love' $(2008,117)$. Freudians would call this libidinal attachment. We have not yet proved this character of emotional involvement.
} 
world (Sartre 2003, 288). I am ashamed of myself as I appear to the other; that I am as the other sees me. Shame, writes Sartre, is by nature recognition (ibid., 246).

Shame is a sign of our ontological dependence on, and vulnerability to, the other. 'Thus in so far as I am my possible, am what I am not and am not what I am - behold now I am somebody! And the one who I am - and who on principle escapes me - I am he in the midst of the world in so far as he escapes me'. Pure shame is not a feeling of being this or that guilty object but the generality of 'being as object' for the other: that the relationship of myself is mediated through the other. If everyday reality is an original relation to the other: shame indicates that this being-for-other is a relationship of conflict. ${ }^{13}$ Concrete relations to others are governed by my attitudes with respect to the object I am for the other. The first attitude seeks release from instrumentality and objectification: if I am an object in the world at least let me be one that is unique - not merely one among others. But the more I try to taste my objectivity the more I am submerged by the consciousness of my subjectivity. Masochism, the logical conclusion, necessarily fails and indeed is - it turns out - the love of this failure. The second attitude aims to take hold of the other's subjectivity through their body. Sadism, the logical conclusion, also fails because it is impossible to reduce the other to mere flesh. There is, Sartre suggests, a perpetual oscillation between sadism and masochism, the two reefs on which desire flounders.

With these examples, Sartre demonstrates, firstly, existential involvement of subjects precedes all possible cognitive knowledge and, secondly, that — at a profound level — I am connected to, aware of and affected by other subjects. ${ }^{14}$ My world is integrated into the other's world and I experience myself as situated in an objective world. Other subjects exist as a prenumerical reality: I am always for some other (indirectly) and for this particular other in a concrete situation (directly). Shame reveals to me that I am this being, not in the mode of 'was' or of 'having-to-be' but as 'in-itself'. Through my being-for-others I am stripped of my transcendence and the other's look marks the death of my possibilities: 'la mort cache de mes possibilitiés'. Of course, these possibilities remain mine but they can also become a means whereby the other realizes his or her own ends. Alienation thus designates not this or that form of objectification but the possibility of objectification in general and, more precisely, the possibility that my possibilities be incorporated instrumentally into the other's project. ${ }^{15}$ This account of the relationship of inter-subjective ontological dependence echoes that found in numerous other phenomenological approaches. Specific to Sartre's Hegelianism is the characterisation of ontological dependence in terms of shame and the relationship to the other which is at best characterised as alternating negation - where I, as for-itself, can negate my object-being or being-for-other.

Honneth (2008) believes that Cavell and Sartre, having shared a common understanding regarding elementary relations of interaction, part company at this point. Whereas Sartre concludes negatively from the existential fact that subject's reciprocally limit each other's freedom for boundless transcendence, Cavell makes a therapeutic reference to the necessary priority of acknowledgement. The question, posed by Honneth, is whether acknowledgement signals a positive or normative stance. The acknowledgement of the other constitutes a non-epistemic prerequisite for linguistic understanding and further signifies an existential fact - that we necessarily affirm the value of another person and their personality. This does

\footnotetext{
$\overline{13}$ There are many ways to recast this relationship. Irigaray, for example, draws on notion of a placental economy to depict a dependent relationship between two.

${ }^{14}$ This seems to reduce the encounter with the other to a visual encounter of being-looked-at, but this would be to simplify what is meant by 'presence'.

${ }^{15}$ Sartre does offer an account of the 'us-object' and the 'we-subject' (see for example 2003, 436 and 445) but the structure of objectification and risk of reification remains throughout.
} 
not mean that subjects approach one another with sympathy, empathy or affection. However, the stance of 'care' or 'involvement' lies at the threshold 'at which that particular form of mutual recognition takes place in which the other person's specific characteristics are confirmed. Even in cases where we view the other negatively or with hostility, we still: 'have a residual sense of not having done justice to their personalities' $(2008,51)$.

Although in comparison, it appears that for Sartre I have already lost something on entry the social symbolic, he actually reveals the complex tonal character of acknowledgement. The intentional character of consciousness means that the other is an object for consciousness but always of a peculiar type. Extending the category of recognition, Sartre can claim of recognition that it is an inter-subjective attitude that involves acknowledgement of the other as subject and he engages with, then refutes, claims that the self and other are either mere objects or, indeed, stable identities. The 'I' is not a unifying force rather it is a synthetic construct held in place by belief. So 'I' am always estranged from, and negotiate, my 'public self'. ${ }^{16}$ To objectify this in terms of personality, 'I recognise that you are like this', is a mental habit whereby perspectives are constructed and ossified. This is a form of reification and its permanent possibility motivates the struggle outlined by Sartre. ${ }^{17}$ To base an ethics of recognition on undistorted recognition of identity would thus be erroneous.

If therapeutic intervention does not aim to recover a lost or forgotten (positive) emotion towards the other, then what is its purpose? Existential psychotherapy can reveal three things: the existential attitude and its relationship to anxiety; the normative pull of recognition and appropriate epistemic virtues. I have already discussed the first in the previous section where I identified Sartre's assertion of ontological nonidentity or estrangement. Here we can see that the relationship between the pre-reflective cogito and the socially intelligible public self is a further site of struggle and introduces a deeper problem for the concept of recognition. What is it that is being recognised? I would suggest that it is the struggle itself and that this can only be acknowledged through certain epistemic virtues. ${ }^{18}$ The normative pull of recognition then depends on two things. The first is that recognition is not a 'choice' nor can it be 'lost'; it is affective and subtends all experience. ${ }^{19}$ The second is that the epistemic virtues adequate to the 'object' in question include flexibility and modesty. Modesty limits the type and range of claim. Cognitive flexibility aims to express the following constellation: the subject is always within a situation, occupies a social role, negotiates their 'external' personality and is nonetheless always in process. Adequacy includes both modesty, cognitive flexibility and points to the adequate participation of the other in knowledge claims. With this in mind, the struggle against the recognition of personality or identity is an appeal that the epistemic approach be motivated by these virtues. ${ }^{20}$

\footnotetext{
${ }_{17}$ See here Sartre's biography of Genet as an example of 'public' alienation.

${ }^{17}$ Honneth (2008) describes reification as neither a category mistake nor a moral wrong but as mental habit of habitually ossified perspective whereby the genuine involved human perspective is neutralised to such a degree it transforms into objectifying thought such that we lose consciousness of the degree to which we owe our knowledge and cognition of other persons to an antecedent stance of empathetic engagement and recognition.

${ }^{18}$ I would identify this with Adorno's suggestion that we should aim to unseal the 'nonconceptual within the concept' in this case of the person.

${ }^{19}$ Honneth (2008) distinguishes between two modes of recognition: the first is where detached observation remains sensitive to and conscious of relation to antecedent recognition and the second is where this relationship has been lost. Even when he refines the meaning of 'lost' to a question of attention, he still assumes that there is 'an objectified' cognitive impersonal stance.

${ }^{20}$ Further work would have to be done to articulate this normative claim in terms of a positive relation to self that Honneth takes to be normative (self-confidence, self-respect, self-esteem). See Necula (2012, 159).
} 
Does this, however, commit us to any positive stance towards the other, a valuing or respect for example and does it commit us to a notion that certain forms of recognition are 'distorted'? ${ }^{21}$ The role of the philosophical therapist is to assist the subject explain conflicts, consider the consequences and personal acceptability of their actions (such as harm) and develop appropriate epistemic virtues. ${ }^{22}$ To be practically useful, other-regarding — indeed even self-regarding - epistemic virtues would have to include modesty, flexibility and adequacy. There is a case to be made, although not here, that these virtues must be accompanied by an emotional affect we might call 'empathy'. ${ }^{23}$ A cognitive orientation animated by these virtues would endeavour not to be instrumental.

\subsection{Being-in-the-World}

A trenchant criticism arising from within critical theory is that existentialism ignores the social aspects of reality and performs a version of philosophical alchemy whereby social experiences of alienation and anxiety are transformed into ontological characteristics and individual experiences: 'It hypostatizes specific historical conditions of human existence into ontological and metaphysical characteristics' (Marcuse 1972, 161). This is to repeat Marx's criticism of Hegelian idealism. Marx alleges that Hegel confuses the making of objects, or externalization, with alienation per se so that an historical relationship to objects is generalized to all external objects. So far I have presented Sartre's case for ontological nonidentity, which can also be called self-estrangement. I have also argued that this can motivate a therapeutically helpful epistemology animated by the virtues of modesty, flexibility and adequacy. In this section I suggest Marcuse alerts us to a potential problem and that to address it we must draw a distinction between self-estrangement and alienation. Although related, these terms refer to discrete processes. This will move us from a concern with the dyadic model of recognition to a social model.

While there is no 'Althusserian break' between early and later writing, the Critique of Dialectical Reason was intended as a corrective to his earlier phenomenology, articulating intersections between political economy, social science and phenomenology. ${ }^{24}$ Disambiguating two senses of alienation, he distinguishes between alienation understood as historical and associated with oppression and exploitation from alienation as our ontological condition of being-in-the-world. In the introduction, Sartre describes his project as a dialectical investigation of alienation and self-alienation: the a priori possibility of human praxis found in human history. ${ }^{25}$ The inference here is two-fold. Firstly, alienation designates three things: a self-relation, a relationship between consciousness and the objects for-consciousness

\footnotetext{
${ }^{21}$ Heter argues that a radical conversion would require the subject not merely to recognise and but also respect the freedom of others so that lucidity and responsibility are necessary but not sufficient conditions for authenticity (Heter 2006, 22). There have been many attempts to derive practical obligations from ontological freedom. See Anderson for why this fails.

${ }^{22}$ For a virtue epistemologist, epistemology is a normative discipline in that in includes norms, rules, duties and values. These promote intellectual well-being and are practically useful.

${ }^{23}$ The claim is that epistemic virtues could not be realised without this affect. 'For the sake of utopia, identification is reflected in the linguistic use of the word outside logic, in which we speak, not of identifying an object but of identifying with people and things' (Adorno 1973 150). This extends Honneth's 'residual sense' of not having done justice to the other's personality.

${ }^{24}$ All references are to the first volume of the Critique. Volume 2 was never prepared by Sartre for publication.

${ }^{25}$ Sartre describes Being and Nothingness as a monument of rationality that ends in irrationalism precisely because it neither coordinates interior with exterior experience nor accounts for 'processes' below consciousness (Sartre 1983, 35 and 42).
} 
(exterioriation) and a political and social process. Secondly, formal structural conditions of alienation are discernible without reference to concrete history. ${ }^{26}$ This latter claim establishes temporal and logical priority of our ontological (alienated) condition in the world: 'Neither un-situated freedom of human consciousness, nor Hegel's relation of consciousness, nor - indeed - Marxist determinist accounts of alienation can explain what comes about through the concrete relation of 'the agent to the other through the mediation of a thing and to the thing through the mediation of the other' (Sartre 1982, 66). ${ }^{27}$

Sartre deploys the concept of alienation in two cases. To clarify the meaning of the term in each case, it is helpful to return to Hegel's Phenomenology of Spirit. The English word 'alienation' actually translates two German words 'Entausserung' and 'Entremdung'. Although Hegel does not employ the term reification (Verdinglichung), he does distinguish between 'strange or estranged' (Entfremdung) and 'making outer, external, or alien' (Entäusserung). Entfremdung carries a sense of loss of essential being and interpersonal estrangement. It is the phenomenological result of spirit positing itself in otherness and has a more restricted use than Entausserung. Entäusserung implies a process of relinquishment, loss, surrender of oneself, but it also conveys 'making objective' in externalization. ${ }^{28}$ This use seems to conflate objectification with externalisation and as such forms the basis for the Marxist critique of Hegelian idealism:

"Hegel cannot conceive of objectification except as resulting in estrangement-hence he substitutes for the category of objectification (Vergegenständlichung) that of alienation (Entäusserung — which, like Vergegenständlichung, has the connotation of positing as objective but which also implies the relinquishment of what is manifested, constituting therefore an alienation)" (Marx 1977, 126). ${ }^{29}$

Unlike Entfremdung, which is always negative, Hegel sees something positive in Entausserung through which spirit becomes objective to itself and so can come to know itself. Until it does come to know itself, individual consciousness is unhappy, inwardly disrupted and not genuinely self-differentiating. Alienation is overcome when consciousness realizes that that which is encountered as an independent object is, in actuality, a part of itself; that I, as spirit, am already nature and nature is already spirit. The therapeutic role of philosophical practice is to bring consciousness to self-consciousness in order to recognize itself in the object and move beyond the state described as unhappy consciousness.

Differentiating the form of objectification from the making of objects, Marx alleges that Hegel confuses the making of objects, or externalization, with alienation per se so that a historical relationship to objects is generalized to all external objects. More pointedly, the Hegelian idealist move collapses the 'consciousness-of-an-object' into the object itself. However one views the awkward relationship between a mind-independent object and the object of consciousness, the Hegelian conflation takes an historical relationship - one of alienation from the produced object - and makes it a confused psychological state - the false belief that objects are mind-independent. The trouble with this, in effect the idealist move, is that the 'making external', 'the alienating', and 'the estranged' are brought together so that alienation is overcome when the object is brought back into consciousness. The issue

\footnotetext{
26 'Consciousness, as apodicitic certainty (of) itself and as consciousness of such and such an object' is the starting point for dialectical reason (Sartre 1982, 51).

${ }^{27} \mathrm{He}$ considers alienation to be a complex phenomenon and its conditions present at all levels of experience.

28 'The root 'ausserung' means manifestation (from ausser-outer) and the prefix 'Ent' indicates establishment of or entry into a new state or relinquishment of an old state'. ibid

${ }^{29}$ For a discussion of translation see (Arthur 1986).
} 
thus becomes surmounting the mind-independent quality of the object-for-consciousness by recognizing it as a product of consciousness. ${ }^{30}$

We have previously established that for Sartre alienation refers to self-estrangement or ontological nonidentity and that this complements the suggestion that self-awareness accompanies an awareness of not-being the object of which it is aware. Although Sartre's selfestrangement is suggestive of Hegel's unhappy consciousness, for Sartre there is no loss of primary identity and no avenue available to overcome nonidentity. The awareness of notbeing the object of which one is aware or on which one acts is a necessary feature of embodied consciousness and is the precondition for Sartre's theory of action. The Critique of Dialectical Reason illustrates how exteriorisation, action on and within the world, can become alienated in a strong sense.

The example of deforestation in the Critique of Dialectical Reason exhibits the relationship between alienated praxis and what Sartre calls 'worked inertia' or the practico-inert. For centuries, Chinese farmers cleared trees to reclaim their plot of land for agriculture. Recurring floods in the locality of China's great rivers are the result of these continual forest clearances. The floods are an unintended result of activities directed towards winning back the land. They are traced back to the inner laws of the material realm: 'clearing the forest leads to an increase in sedimentation of soil and raises the level of the river above the plain' (Knecht 1980, 206). The original intention, recovering land for agriculture, was 'made other' (Poster 1979, 59). There is thus both objectified activity and its unintended consequence; which Sartre designates as counter-finality.

The realm of objectified action provides the context for alienation but alienation is not the simple result of objectification or counter-finality: it includes the structure of plural praxis the involvement of other people. Alienation in this example refers to the moment when the original praxis - forest clearance to provide fertile farming land - was altered. To the moment when what was once an act of reclamation became a condition of erosion: 'deforestation as the action of Others becomes everyone's action and Other in matter; objectification is alienation, and at first this primitive alienation does not express exploitation, though it is inseparable from it, but rather the materialisation of recurrence' (Sartre 1982, 163). The floods occurred because many farmers cleared the forest without a plan and in ignorance of the consequences. 'The praxis of plurality generated results that no longer corresponded to initial intentions'.

It is not yet quite obvious whether this alienation, what Sartre names 'counter-finality', is a necessary feature of praxis, an integral feature of acting in the world alongside other people, or whether there is something historically specific to it. He certainly seems to be saying that it is disempowering for an individual to have his or her actions accommodated into a series because the series itself seems to develop its own momentum.

A distinction must be made: alienation in the Marxist sense begins with exploitation. Should we go back to Hegel who sees alienation as a constant characteristic of all kinds of objectification? Yes and no. We must recognise that the original relation between praxis as totalisation and materiality as passivity obliges man to objectify himself in a milieu which is not his own and to treat an inorganic totality as his own objective reality. It is this relation between interiority and exteriority which originally constituted praxis as a relation of the organism to its material environment' (Sartre 1982, 227).

\footnotetext{
30 'actual estrangement is according to its innermost, hidden nature (which is only brought to light through philosophy) nothing but the manifestation of the estrangement of the real human essence, of selfconsciousness' (Marx 1977, 134).
} 
The designation of this as 'alienation' depends on an asymmetry or estrangement between intended ends and outcomes. Any idea of emancipation would thus imply accordance between a project and its rational realisation. There are certainly echoes here of Marx's account of emancipation from irrational relations of production.

By triangulating the notion of alienation, Sartre brings together the making of objects, counter-finality and serialisation. ${ }^{31}$ In a series, people internalise the passivity of the practico-inert and become other than themselves (ibid., 66). The individual appears as any other, 'whomever', depersonalised and nameless in the midst of a multitude (Knecht 1980, 194). The practico-inert presents a pre-given order for relations so that relationships between individuals appear not 'as a production of synchronizing praxis but rather as the actualization of a predetermined reality by social atoms' (Sartre 1982, 268). Here Sartre denotes the features of social structure or system whereby people are organised in a systematic fashion according to characteristic relationships which include enduring bonds or established patterns of interaction regulated through norms and values. Recurrent, habitual and normative patterns give shape to, but also limit and constrain, situations. Does alienation always emerges from the relationship between individual activity and multiple praxis or only under certain conditions?

If alienation is identified with objectivity and counter-finality, or individual and multiple praxis, then alienation becomes the rule of objectivity in historical society and this means that there is no deliverance from the necessity of alienation. In such a case, from a critical theory perspective, Sartre would be guilty of internalising an historical and contingent state of affairs and making it a necessary feature of how human beings engage in the world. It could thus be argued that Sartre's definition of alienation - as the dispersion of human intention in objectivity - is incompatible with Marxism and that, due this characterisation, his political response retreats into a nostalgia of original subjectivity (Poster 61). However, whilst there are Hegelian echoes here, of the self becoming other when it objectifies itself, Sartre points to the context of history which he characterises in terms of scarcity. According to Poster, Sartre's extended use of alienation actually enables a wider extension of the term than in Marx and indeed overcomes the productivist tendencies whereby exploitation, alienation and oppression are limited to the experience of remunerated labour (Howie 2010, 24-32 ).

'As such, the extension of alienation to practico-inert provides a superior basis for critical theory... The connection between practico-inert and alienation enables the critical historian to explore the multitudinous forms that inhumanity has taken in the process of overcoming scarcity. Sartre's contention deserves serious consideration: human beings have been alienated not only by capitalist organisation of labour but by all actions which introduce into human affairs the counter-finality of the practico-inert' (Poster 1979, 64).

Alienation thus designates 'morally and politically neutral' characteristics of 'worldmaking'. Under certain conditions, such as scarcity, these can become aggravated. In this way, Sartre's extended use of alienation as 'world-making' facilitates a critical historiography attuned to patterns of power, irrationality and social asymmetry across history. ${ }^{32}$

A subdued level of participation in 'world-making' would be a critical case of alienation and correspond to a range of emotional affects as well as psychological distress. But it is

\footnotetext{
${ }^{31}$ Seriality is the reciprocal mediation of a plurality and practico-inert.

32 This use of the term could be said to correspond to the development of instrumental reason in the Dialectic of Enlightenment.
} 
'scarcity that is viewed as lying at the heart of violence in human relationships - and not the mere existence of the other as witness and critic' (Cannon 1991, 191). To extend this, we could say that what requires recognition here is not individual or specific group-identity but 'the status of groups in full political participation'. Misrecognition, or the failure of recognition, designates not a failure to acknowledge personality but rather social subordination which is, according to Fraser, a situation where one is prevented from participating as a peer in social life (Fraser 2002, 24). ${ }^{33}$ Sartre's account of the primarily (self) relation as one that is divided and estranged is not the internalisation of social and historical experiences of alienation but does imply a permanent possibility of reification and subordination: the form that externalisation - under certain conditions - may take. Taken together, Being and Nothingness and the Critique of Dialectical Reason, provide the philosophical support to the principle that reciprocal recognition and status equality is a matter of justice rather than ethics.. ${ }^{34}$

\section{Alienation and Therapy: Concluding Remarks}

Existentialist psychotherapy is aligned to the ancient tradition of philosophical therapy rather than with psychology and, indeed, psychoanalytic therapy. The phenomenological method is suited to the demands of clinical metatheory: it allows for an understanding of the meaning, significance and values of actions without commitment to a theory of underlying flows or forces. Whereas a psychotherapist might try to identify forgotten or hidden episodes that influence current emotional states, a philosophical therapist aims to reveal beliefs that have not been well established and habitual behaviours that are harmful. The therapeutic role of philosophical practice is to bring consciousness to reflective awareness that it is not one either with itself or with the object-for-consciousness and that identity is always 'elsewhere' and more often than not rather anxious. It also provides a bridge between recognition, premised on the acknowledgement of nonidentity and corollary epistemic virtues, and a justice model of recognition, premised on parity of participation.

Open Access This article is distributed under the terms of the Creative Commons Attribution License which permits any use, distribution, and reproduction in any medium, provided the original author(s) and the source are credited.

\section{References}

Adorno TW (1973) Negative dialectics. Routledge and Kegan Paul, London

Aronson R (1987) Sartre's second critique. The University of Chicago Press, Chicago and London

Arthur CJ (1986) Dialectics of labour: Marx and his relation to Hegel. Basil Blackwell, Oxford Beauvoir de S 1976 (1948) The ethics of ambiguity (trans: Frechtman B). Citadel Press, London

Busch T (1980) Sartre's use of the reduction: being and nothingness reconsidered. In: Silverman H, Elliston F (eds) Jean-Paul Sartre: contemporary approaches to His philosophy. Duquesne University Press, Pittsburgh, pp 17-29

\footnotetext{
33 'On the status model misrecognition arises when institutions structure interaction according to cultural norms that impede parity of participation' (Fraser 2002, 24). Claims for recognition aim to de-institutionalise patterns of cultural value that impede parity of participation and to replace them with patterns that foster it (ibid., 25).

${ }^{34}$ The question 'why we should be committed to the principle of justice' is addressed by Simone de Beauvoir in Ethics of Ambiguity where she derives a commitment to liberty from ontological freedom and intersubjectivity.
} 
Butler J (1997) The psychic life of power: theories in subjection. Standford University Press, Standford Cannon B (1991) Sartre and psychoanalysis: an existentialist challenge to clinical metatheory. University Press of Kansas

Foucault M (1986) The care of self: the history of sexuality: 3 (trans: Hurley R). Penguin Books, London

Fraser N (2002) Recognition without ethics. In: Lash S, Featherstone M (eds) Recognition and difference: politics, identity, multiculture. Sage, London, pp 21-42

Gowans C (2010) Medical analogies in Buddhist and Hellenistic thought: tranquility and anger. In: Carlisle C, Ganieri J (eds) Philosophy as therapeia. Cambridge University Press, Cambridge, pp 11-33

Hadot P (1995) Reflections on the idea of a 'cultivation of the self. In: Hadot P, Davidson A (eds) Philosophy as a way of life. Blackwell, Oxford

Hegel GWF (1977) Phenomenology of spirit (trans: Miller, AV, with analysis of the text and foreword by Findlay JN). Oxford University Press, Oxford

Honneth A (2008) Reification: a new look at an old idea (trans: Ganahl J). Oxford University Press, Oxford

Howells C (ed) (1992) Cambridge companion to Sartre. Cambridge, Cambridge University Press

Howie G (2010) Between feminism and materialism: a question of method. Palgrave, New York

Knecht I (1980) Seriality: a ground for social alienation. In: Silverman HJ, Elliston FA (eds) Jean-Paul Sartre: contemporary approaches to his philosophy. Duquesne University Press, Pittsburgh

Marcuse H (1972) Studies in critical philosophy (trans: de Bres J). New Left Books, London

Marx K (1977) Economic and philosophic manuscripts of 1844. Lawrence and Wishart, London

Morris PS (1976) Sartre's concept of person: an analytic approach. University of Massachusetts Press, Amherst

Morris K (2008) Sartre. Basil Blackwell, Oxford

Necula R (2012) Being oneself in another: recognition and the culturalist deformation of identity. Inquiry 55(2):148-170

Poster M (1979) Sartre's Marxism. Pluto Press, London

Sartre JP 1957 (1936/7) The transcendence of the ego: an existentialist theory of consciousness (trans: Forrest Williams and Robert Kirkpatrick). Noonday Press, New York

2003 (1943) Being and nothingness (trans: Barnes H). Routledge, London and New York

1982 (1960) Critique of dialectical reason (trans: Rée J). Verso, London

1983 (1969) The itinerary of a thought in Jean-Paul Sartre: between existentialism and marxism (trans: Matthews J). Verso, London

Storm Heter T (2006) Authenticity and others: Sartre's ethics of recognition. In: Sartre International Studies $12: 17-40$

Warnock M (1972) Introduction to psychology of the imagination by Jean-Paul Sartre. Methuen, London 